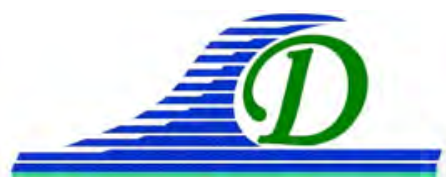

$$
\begin{gathered}
\text { XIII }^{\text {èmes }} \text { Journées Nationales Génie Côtier - Génie Civil } \\
\text { Dunkerque, 2-4 juillet } 2014
\end{gathered}
$$

DOI:10.5150/jngcgc.2014.072 (C) Editions Paralia CFL

disponible en ligne - http://www.paralia.fr - available online

\title{
Amélioration et renforcement de sol à l'arrière des quais
}

\author{
Serge LAMBERT ${ }^{1}$ \\ 1. Keller Fondations Spéciales, Duttlenheim, France. \\ serge.lambert@keller-france.com
}

\section{Communication non présentée}

\section{Résumé :}

Pour répondre à l'augmentation du trafic de transport maritime par conteneurs et offrir une alternative multimodale, les ports aménagent à travers le monde des nouveaux terminaux à conteneurs. Ils se composent souvent de quais avec de forts tirants d'eau, adossés à une surface aménagée directement connectée aux réseaux routier, ferroviaire ou fluvial. À l'arrière du mur de quai constitué de caissons, palplanches, paroi moulée ou combi-wall, le terre-plein est habituellement remblayé par des matériaux issus du dragage effectué en mer sur une zone proche du port. Ces remblais sableux doivent être au préalable compactés ou consolidés en présence d'eau, afin d'éviter des tassements qui peuvent être très importants sous les surcharges d'exploitation ou sous la charge des portiques de conteneurs ou tout simplement sous leur propre poids. Cet article a pour objet d'aider les concepteurs à choisir le procédé d'amélioration ou renforcement de sol le mieux adapté en fonction du contexte géotechnique afin d'atteindre les objectifs fixés. Quelques outils sont donnés pour fixer des objectifs de compacité atteignables par les différents procédés d'amélioration de sol.

Mots-clés : Vibrocompactage, Colonnes ballastées, Sous-consolidé, Renforcement de sol, Quai, Consolidation de sol. 
Thème 4 - Ouvrages portuaires et offshore 
XIII ${ }^{\text {èmes }}$ Journées Nationales Génie Côtier - Génie Civil Dunkerque, 2-4 juillet 2014 
Thème 4 - Ouvrages portuaires et offshore 
XIII ${ }^{\text {èmes }}$ Journées Nationales Génie Côtier - Génie Civil Dunkerque, 2-4 juillet 2014 
Thème 4 - Ouvrages portuaires et offshore 
XIII ${ }^{\text {èmes }}$ Journées Nationales Génie Côtier - Génie Civil Dunkerque, 2-4 juillet 2014 
Thème 4 - Ouvrages portuaires et offshore 
XIII ${ }^{\text {èmes }}$ Journées Nationales Génie Côtier - Génie Civil Dunkerque, 2-4 juillet 2014 
Thème 4 - Ouvrages portuaires et offshore 